\title{
Rebuilding transformation strategies in post-Ebola epidemics in Africa
}

\author{
Ernest Tambo ${ }^{1,2^{*}}$, Chryseis F. Chengho ${ }^{3}$, Chidiebere E. Ugwu ${ }^{4}$, Isatta Wurie ${ }^{5}$, Jeannetta K. Jonhson ${ }^{6}$ \\ and Jeanne Y. Ngogang ${ }^{1}$
}

\begin{abstract}
Rebuilding transformation strategies in post-Ebola epidemics in West Africa requires long-term surveillance and strengthening health system preparedness to disease outbreak. This paper assesses reconstruction efforts from socio-cultural, economic and ecological transformation response approaches and strategies in improving sustainable survivors and affected communities livelihood and wellbeing. A comprehensive approach is required in the recovery and rebuilding processes. Investing in rebuilding transformation requires fostering evidence-based and effective engaging new investors partnership strengthening, financing community-based programmes ownership, novel socio-economic innovations strategies and tools against the evolving and future Ebola epidemics. Thus, there should be improved community partnership, health and economic rebuilding programmes to address mistrust and care underutilization, poverty and care access inequity at all levels. Implementing effective post-Ebola national 'One Health' approach coupled with climate change mitigation and adaptations strategies is urgent public health needs aiming at improving the quality healthcare access, delivery trust and uptake in anticipation of EVD immunization program, productivity and emerging economy.
\end{abstract}

Keywords: Recovery, Reconstruction, Ecological, Transformation, Ebola, Preparedness, Resilience, Response, Africa

\section{Multilingual abstracts}

Please see Additional file 1 for translations of the abstract into the five official working languages of the United Nations.

\section{Introduction}

Almost four decades since Ebola epidemic was first identified, we have learnt that prevention measures are better than emergency responses to infection with the Ebola virus that causes severe haemorrhages and multiple organs failure. In confronting the invisible Ebola virus in Africa, neither Ebola infection, nor Ebola Virus Disease (EVD) survivors breast milk and semen persistence, social stigmatization and disability occur in a vacuum [1, 2]. Lessons learnt from West African public health system have shown the unpreparedness of the national health systems toward EVD preparedness,

\footnotetext{
* Correspondence: tambo0711@gmail.com

${ }^{1}$ Higher Institute of Health Sciences, Université des Montagnes, Bangangte, Cameroon

${ }^{2}$ Africa Disease Intelligence and Surveillance, Communication and Response (Africa DISCoR) Institute, Yaoundé, Cameroon

Full list of author information is available at the end of the article
}

prevention and containment $[2,3]$. Revamping recovery and rebuilding of the local and national health systems including emergency response requires access to and use of medical and stockpile system network in tackling the existing patchy and sporadic supply chain procurement and management $[1,3]$. Moreover, addressing the drawbacks of surveillance, detection and tracking systems of pathogen (s) transmission dynamics before the onset of potential threat and outbreak have not been achieved in most African countries [2, 4, 5]. The threats posed by EVD survivors and long-term latent asymptomatic reservoirs can be amplified by sociobehavioural and ecological risks factors as well as economic and epidemiological determinants $[4,6]$. Thus, accelerating the recovery and rebuilding process in affected countries has immense potential benefits by positively influencing the local communities across Africa that outwitting the persistent pattern of infectious disease threats and outbreak burden is real. In addition, better understanding of risk factors should be invigorated by collaborative joint operational Ebola research and development agenda toward evidence-based 
decision making policies and programmes [2, 5-7]. Forecasting in knowing the nature of the EVD epidemic in a given African context, it is crucial that contextual, robust and sustainable recovery and reconstruction programmes and strategies are developed and implemented with sustainable financial, economic and policy management mechanisms. These could accelerate and sustain community engagement and resilience required for continuous social mobilization, health education and awareness, and promoting regulatory reforms that will enhance public health strengthening and standard interventional practices. Also, spring up local innovations in local and international preparedness and emergency response measures enhancements is needed in threats and epidemics capacity development and management from global health to local health-care workers and laboratory staff preventive and smart response strategies perspectives [4, $7,8]$. There is an urgent need for greater leadership commitment and investment efforts in integrated medical, psychosocial and economic recovery and reconstruction needs and programs. These include intensifying community engagement and resilience, citizenry awareness and education, efficient and sustainable financial and market development and benefits. Strengthening of EVD funding of recovery programmes and positive human socio-cultural behaviour will improve the national EVD recovery programmes such as Ebola national immunization, public health security and economic prosperity. Improving the lives and livelihood of the survivors and affected communities aiming at short and long-term individual, community and governments joint engagement and commitment into primary and secondary recovery and reconstruction projects and programmes performance and effectiveness. These include providing the enabling recovery and rebuilding environment (political, regulations and laws), national security and peace, assisting new investors and entrepreneurs, tax relief and cross-border trade incentives, reducing Ebola virus resurgence from survivors, survivors access to and use of psycho-social and care delivery counselling, enhanced schools or faith-based education curriculums and skills training including safe cultural burial practices at all levels, boosting employment and regain of income, facilitating access to financial support or loan, accelerating local/national disaster risk reduction and emergency response implementation and actions plans awareness.

Hence, this paper examined recovery and rebuilding programmes through socio-cultural behaviour, economic and ecological approaches and strategies in improving contextual, effective and sustainable postEVD outbreak transformation era, assurance, trust and empowerment in early alertness and resilience culture amongst survivors, affected communities Africa and worldwide.

\section{Rebuilding effective national health systems and community-based programs}

The variation in the West Africa Ebola outbreak impact provided new dimensions on the drawbacks and challenges of the health system care practice, coupled with potential survivors' persistent disease transmission dynamics and spread. Strengthening the primary health systems, community engagement and social mobilization are crucial in mitigating the effectiveness and sustainability of first and second order impacts rebuilding and recovery programmes and activities in affected populations and Ebola survivors. These include community assessment of overall needs and priority, aligning needs and demand based on vertical and horizontal equitable support programmes from government and local private sector, International Monetary Fund (IMF) post-Ebola relief fund and United nations (UN)-global health security agenda $[5,6,9,10]$. For example scaling up access to and uptake of sustainable recovery programmes including EVD national immunization coverage in improving maternal and child healthcare, family planning and breastfeeding, survivors counselling and psychosocial centers, early detection and diagnostic tools for prompt treatment of asymptomatic case(s) resulting from Ebola virus persistence in breast milk and semen of survivors in affected areas, microfinance support, policy and regulation reforms. Moreover, fostering local and foreign investment, local microfinance and entrepreneurship activities in fastening recovery and reconstruction programmes effectiveness are needed. Strategic rehabilitation and reconstruction policy and governance is needed to scale up access to equitable prevention service and justice, gender-based violence mitigation advocacy and contextual technical mentorship support. Nurturing, inspiring and empowering talents, local resilience and performance, and standard practices adherence initiatives is crucial for the overall healthy development and economic growth $[1,10,11]$. Foremost short and long-term commitment of governments and new stakeholders partnership and collaborative investment efforts should be focused on financial, socio-economic and educational recovery opportunities, tax relief and health insurance, agricultural development toward food security and sanitation programs; population access to flexible microfinance loan and grant applications for business development, youth-targeted skills empowerment and economic diversification (Table 1).

Strategic global post-EVD epidemics assistance in recovery and rebuilding programmes and activities institutionalization is imperative in improving care workforce and health commodities, access to and use of diagnostics and care delivery packages to remote rural settings $[6,8,12]$. Substantial success rely on improving information communication, training of field workers, 


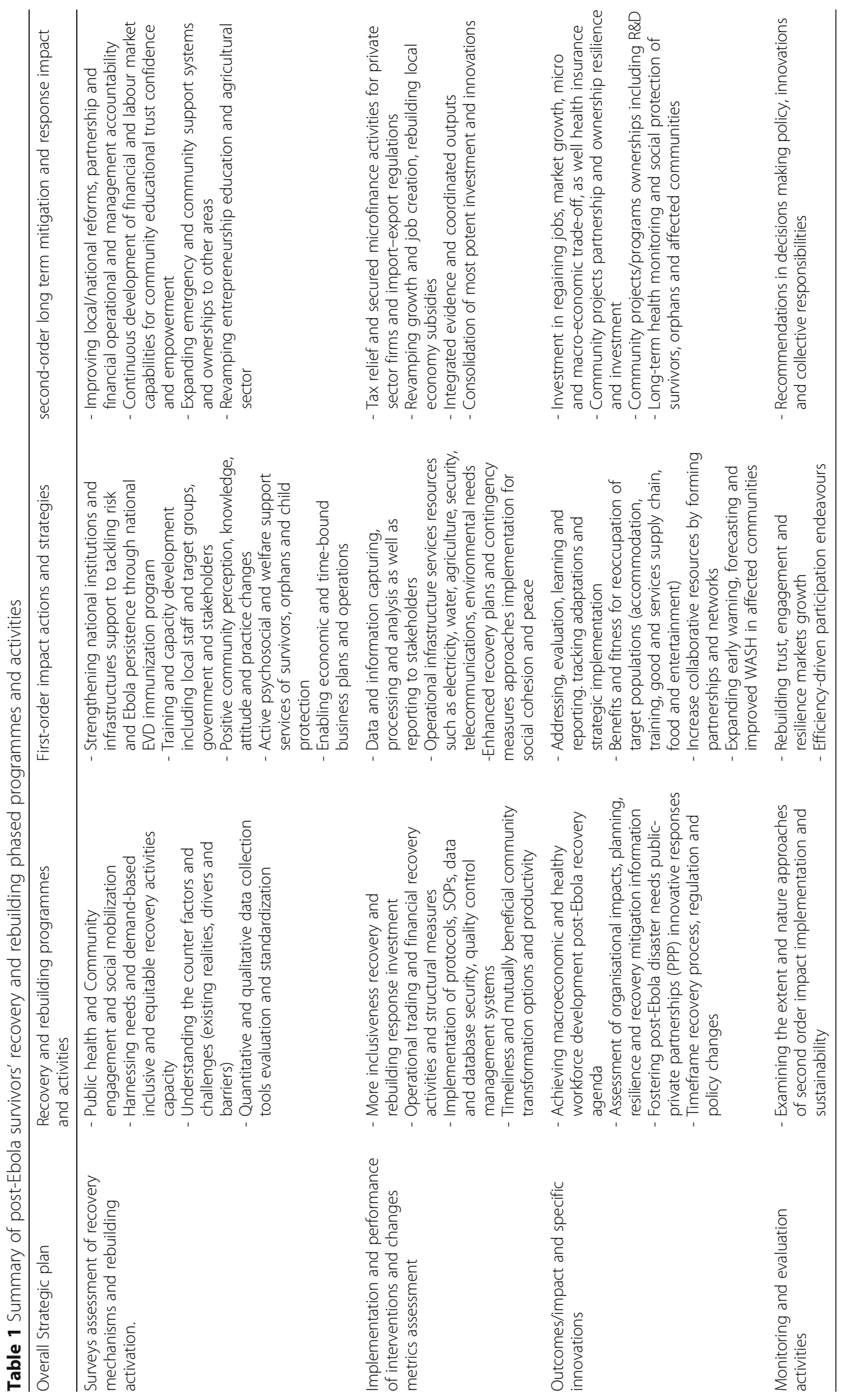


care-providers and epidemiologists, leadership management and accountability, quality standards at local and national levels $[3,7,8]$. Setting up evidence-based comprehensive phased approaches such as first and second-order impact agenda is needed for the implementation of quality management policies, process and tools in rehabilitating the affected populations and survivors as well as reconstruction of the affected communities' socioeconomic regains supported by the community and all stakeholders [1, 13, 14] (Table 1).

Although recovery is a complex process, community engagement and social mobilization activities play an important role in developing and implementing operational and transparent evidence-based rebuilding and recovery programmes $[8,9]$. Moreover, community perceptions and vision of decision makers in building comprehensive and integrated evidence-based approaches and strategies is crucial in strengthening emergency local and national health systems, psychosocial and economic recovery and management capacities imperative to public peace and security for partnership commitment and investment $[8,9,12]$. Understanding the local determinants can also contribute to increasing the frequency of public health needs, programs and social services delivery amongst communities and populations who are at greater risk or disease outbreak disaster. Response policies and programs should be rooted within evidence-based frameworks and standards practices $[8,12]$. This should include a multidisciplinary training and workshops, interactive discussions, group work and individual/collective projects in answering some key socio-cultural and health issues and players [8-10]. What and how do we communicate with each other? How do we plan together? Who is responsible for doing what and when? Thus, implementation of effective and efficient community capacity to responses are of greater opportunities in establishing effective community sensitization activities using the survivors. Fostering accessibility of care centers and laboratory support services should be primarily based on proactive community health workers and volunteers capacity building and training in early risk communication, safe isolation, quarantine and contact tracing, safe burial practices and preventative measures adherence [10-12]. Strengthening the health systems operational preparedness and readiness plans is needed in improving availability of stockpile and supply chain management system as well as sustainable mechanisms and maximizing the advantages of direct technical assistance and guidance from stakeholders toward community recovery projects/programs ownership at all levels $[15,16$, 17]. Establishing emergency preparedness plans and coordinated response units and activities is needed by implementing disaster risk reduction and National Framework for Health Emergency Management (NFHEM)with adequate coordination and planning mechanisms that can be mobilized during emergencies or disease outbreak in line with Sendai declaration [7]. The role of communication education in mediating the intersections among these variables is critical in its contribution to decreasing the spread of EVD and mitigating the impact on individuals and the education system $[8,11$, 17, 18]. For example, surveillance and information sharing increased at the neighbouring borders districts of Guinea, Liberia and Sierra Leone with intense EVD transmission with Côte d'Ivoire, Mali and Senegal [1, 9]. Such an innovative system supports the reinforcement of extra-curricular and non-formal education interventions for adults and drop out, door to door household campaigns as well as aged population in the community $[5,13,17]$. Health education and promotion should be tailored towards culturallysensitive and age appropriate curricula, taught or disseminated by well-trained teachers/preachers and/or community trained health promoters, community workers or mobilizers with practical demonstrations of opportunities and gains on individual, family and community at large positive transformations and impact $[3,13-15,19]$ (Table 1).

As the root causes to vulnerability are socio-cultural, economic and poverty related in nature, the educational system should be transformed in a way to prevent EVD and other future epidemics $[7,16,17]$. Social mobilization and education could properly resource and support schools and community to ensure quality programmes and measurement of meaningful results with proven tools and methodologies being easily adapted to communityspecific contexts including scaling up cultural and behavioural preventive measures and tools $[1,8,16]$. Lessons learnt coupled with technical assistance could contribute to an integrated community preparedness projects and knowledge-base that features cross-fertilization and improvement in local capacity and response delivery [1618]. The African educational system must be innovative to local realities in order to inform, mobilize and reinforce community effective planning, early warning alerts indicators and prompt efficient response to risk and epidemic or disaster. Monitoring and evaluation of socio-cultural and ecological factors in these communities is core in improving quality evidence-based decision-making and care delivery interventions delivery on persisting survivors neurological, musculoskeletal and ocular effects for significant socio-cultural transformation and development at all levels $[1,4,7,9,16,20]$. Such collective behaviour changes could lead to improvement in health seeking attitudes, cultural emancipation in safe burials practices, compliance to standard protective measures and quality health outcomes toward advanced health care system benefits regionally [16-18]. 


\section{Leveraging on citizenry rebuilding resilience and empowerment methods}

The exchange of experience on social norms and collective behaviour and their impact on both driving infection and influencing prevention planning and management efforts should be encouraged. Also, promoting social environment of understanding and tolerance that enables learning and transformation to more positive behaviour adaptations should be encouraged [2, 13, 21-23]. To optimize such goals, community soft environment awareness including drama, theatre shows, media, poems and others projects should be incorporated into the social media and education programs [13, 23, 24]. Leveraging on local apolitical champions and international leaders to communicate vital measures and instructions are necessary $[1,4,10]$. Therefore, the need to create local based risk reduction and emergency responses and interventions mechanisms where actors are free to reflect critically on their historical beliefs and traditions, is necessary in implanting the enabling working environment $[12,15]$. Likewise, fostering accessibility to health services including protective measures uptake, provision of guidance and assistance, community mobilizers/watch teams, workshops, groups discussions and campaigns, sensitization on safe burial and transformation programmes are important $[2,19]$ (Table 1).

Fostering efficient formal and informal skills and knowledge development and professional improvements in health, management, agriculture production and food security (fertilizers, machinery) is paramount in achieving long-term hope and increasing household cash crops and productivity [19]. This will increase the overall local food auto-sufficiency and economy, by expanding the structure of national and regional economic expectations and growth [10].

While post-Ebola recovery and rebuilding actions plans also require building integrated capacity within local and neighbourhoods context, adapting proactive and effective to the new environmental and culture, targeted resilient mass media and social media information dissemination of proven solutions in improving awareness and empowerment is imperative in regaining community trust and speeding civic accountability $[9,13,25,26]$.

\section{Transforming contextual behavioural and attitudes information dissemination strategies}

Historically, African communities have strong traditional practices for dialogue and information dissemination through local means including drums, chief messengers, oral history and anecdotes and other cultural ways of keeping with ancestors for promoting mobilization, communication, caring for the sick and safe burial practices $[8,14]$. Social cohesion, inclusive growth and community compassionate support in supporting the shared social, cultural and religious values and realities are the foundation to mitigate infectious diseases risks by finding acceptable and resilient preventative ways $[8,27,28]$. It is difficult to ascertain what technique or combination of tools and approaches could guarantee that Ebola would neither resurge nor spread in the future $[29,30]$. Hence, the needs for robust and innovative health education curricula and interventions implementations in schools and faith groups (childhood, adults women and elderly) to boost understanding of cultural norms, environmental and socio-economic contexts to risk and epidemics. Particularly, empowering survivors and citizenry with new knowledge and skills are necessary in adopting positive attitudes and practices against evolving risk and epidemics. These should emphasize on increasing contextual awareness and vigilance, counselling on sexual and reproductive health and family planning, use of condom, improved HIV/EVD screening programs, enhanced access to water, sanitation and hygiene which should be constantly reinforced based on sound understanding and freedom of choice including Africa oral history and anecdotes [5, 8, 29, 31]. Furthermore, the importance of innovative evidence-based knowledge and practices of socio-cultural and behavioural practices in EVD and other epidemic prevention, care and mental support and counselling should be entrenched in African traditions and story-telling [19, 32, 33]. Current efforts in community mobilization campaigns and intense communication and dialogue with communities have recorded much progress on positive attitudes to health seeking and traditional practices in reducing future EVD incidence and fatality in West Africa epicentres, DR Congo and other proxy-countries [3, 8, 22, 28, 34]. Promotion of preventive measures and health education among adolescents and youngsters should be expanded at all levels. Simple and reliable multistage technical skills development and training empowerment, drama and theatre performances by local eloquent heroes such as entrepreneurs, footballers, musicians, comedians and other stakeholders could be crucial in rebuilding trust and hopes in cultural, social and behavioural recovery and reintegration [8, 35-38]. Collaborative community-driven projects ownership and active social accountability and transparency are needed in rolling out national EVD immunization program which is crucial positive step including population-based awareness, blood, semen and breast-milk testing assessment for survivors, public health strengthening for socio-economic transformation and growth $[8,14,19,39]$.

\section{Conclusion}

Although Ebola epidemics 2014-2016 was an immense impediment and challenges in economic development and growth in West Africa and Africa in general, 
investing at promoting rapid recovery and reconstruction programs is crucial. Better investment including local private sector collaborative and resources allocation in contextual and effective impact mitigation approaches, rebuilding and strengthening health systems capabilities are vital against evolving outbreaks consequences. Understanding and monitoring the social and behavioural dimensions needs to be active and sustained to guarantee the effectiveness of survivors' resilience support systems. Promoting innovative and inclusive community-based multi-disciplinary and inter-sectoral entrepreneurship approaches should be enhanced. Social responsibility and solidarity, health promotion, counselling on positive socio-behavioural, health and cultural attitudes and behavioural changes are crucial in developing trust and confidence in national/regional reconstruction. Sustainable community-based partnership is vital in fostering community engagement and education, and shared values. Implementing local/national 'One Health' approach in early risk communication, timely resilience and emergency response projects/programmes ownership are needed to keep pace with positive socio-cultural and behavioural mitigation approaches and shared economic benefits across Africa.

\section{Additional file}

Additional file 1: Multilingual abstracts in the five official working languages of the United Nations. (PDF $639 \mathrm{~kb}$ )

\section{Abbreviations}

EVD: Ebola virus disease; HIV: Human immune deficiency virus; IMF: The International Monetary Fund; SDG: Sustainable Development Goals; UHC: Universal Health Coverage; UN: The United Nations

\section{Acknowledgments}

Dedicated to all Ebola survivors, orphans and deceased families.

\section{Funding}

No funding was received.

\section{Availability of data and materials}

These will be made available as datasets upon publication.

\section{Authors' contributions}

ET designed the search strategy, carried out the data collection and review, and wrote the primary draft of the paper. CFC, UCE, WI, JKJ and JYN provided additional information. CFC and ET summarized the manuscript. All authors read and approved the final version manuscript.

\section{Competing interests}

The authors declare that they have no competing interests.

\section{Consent for publication}

All authors provided their consent for publication.

\section{Ethics approval and consent to participate}

Ethical approval was obtained from the Ethical Review Committee (ERC) at Universite des Montagnes, Bangante, Cameroun.

\section{Author details}

${ }^{1}$ Higher Institute of Health Sciences, Université des Montagnes, Bangangte, Cameroon. ${ }^{2}$ Africa Disease Intelligence and Surveillance, Communication and
Response (Africa DISCoR) Institute, Yaoundé, Cameroon. ${ }^{3}$ Department of Health and Life Sciences, University of Coventry, Coventry, Leicester, UK. ${ }^{4}$ Faculty of Basic Medical Sciences, Department of Human Biochemistry, NnamdiAzikiwe University Awka, Nnewi Campus, Awka, Nigeria. ${ }^{5}$ Department of Chemical Pathology, College of Medicine and Allied Health Sciences, University of Sierra Leone, Freetown, Sierra Leone. ${ }^{6}$ Public Health Development Initiative (PHDI), Monrovia, Liberia.

Received: 12 September 2016 Accepted: 6 March 2017

Published online: 10 May 2017

\section{References}

1. Chughtai AA, Barnes M, Macintyre CR. Persistence of Ebola virus in various body fluids during convalescence: evidence and implications for disease transmission and control. Epidemiol Infect. 2016;144(8):1652-60.

2. Flaherty J. Recovery brings uncertain future. Nurs Child Young People. 2015;27(4):15.

3. Frieden TR, Damon I, Bell BP, Kenyon T, Nichol S. Ebola 2014-new challenges, new global response and responsibility. N Engl J Med. 2014;371(13):1177-80. doi:10.1056/NEJMp1409903. Epub 2014 Aug 20.

4. WHO Ebola Response Team. Ebola virus disease in West Africa-the first 9 months of the epidemic and forward projections. N Engl J Med. 2014; 371(16):1481-95.

5. Tambo E, Ugwu EC, Ngogang JY. Need of surveillance response systems to combat Ebola outbreaks and other emerging infectious diseases in African countries. Infect Dis Poverty. 2014:3:29. doi:10.1186/2049-9957-3-29. eCollection 2014

6. WHO Ebola Response Team. Ebola Virus Disease in West Africa - The First 9 Months of the Epidemic and Forward Projections. N Engl J Med. 2014; 371(16):1481-95. doi:10.1056/NEJMoa1411100.

7. Tambo E, Yah CS, Ugwu CE, Olalubi OA, Wurie I, Jonhson JK, Ngogang JY. Fostering prevention and care delivery services capability on HIV pandemic and Ebola outbreak symbiosis in Africa. J Infect Dev Ctries. 2016;10(1):1-12. doi:10.3855/jidc.6875.

8. Siettos C, Anastassopoulou C, Russo L, Grigoras C, Mylonakis E. modeling the 2014 ebola virus epidemic - agent-based simulations, temporal analysis and future predictions for Liberia and Sierra Leone. PLoS Curr. 2015; 7. doi: 10.1371/currents.outbreaks.8d5984114 855fc425e699e1a18cdc6c9.

9. Edelstein M, Angelides P, Heymann DL. Ebola: the challenging road to recovery. Lancet. 2015;385(9984):2234-5.

10. Ye Y, Ellenberg RM, Graham KE, Wigginton KR. Survivability, partitioning, and recovery of enveloped viruses in untreated municipal wastewater. Environ Sci Technol. 2016;50(10):5077-85.

11. lyengar P, Kerber K, Howe CJ, Dahn B. Services for mothers and newborns during the ebola outbreak in liberia: the need for improvement in emergencies. PLoS Curr. 2015;7. doi: 10.1371/currents.outbreaks. 4ba318308719ac86fbef91f8e56cb66f.

12. Vygen S, Tiffany A, Rull M, Ventura A, Wolz A, Jambai A, Porten K. Changes in Health-Seeking Behavior Did Not Result in Increased All-Cause Mortality During the Ebola Outbreak in Western Area, Sierra Leone. Am J Trop Med Hyg. 2016;95(4):897-901.

13. Folayan MO, Haire BG, Brown B. Critical role of ethics in clinical management and public health response to the West Africa Ebolaepidemic. Risk ManagHealthc Policy. 2016;9:55-65.

14. Soka MJ, Choi MJ, Baller A, White S, Rogers E, Purpura L, et al. Prevention of sexual transmission of Ebola in Liberia through a national semen testing and counselling programme for survivors: an analysis of Ebola virus RNA results and behavioural data. Lancet Glob Health. 2016;4(10):e736-43.

15. Dhillon RS, Yates R. Building back better: priorities for Ebola-affected countries. Lancet Glob Health. 2015;3:e435-6.

16. Bowles J, Hjort J, Melvin T, Werker E. Ebola, jobs and economic activity in Liberia. J Epidemiol Community Health. 2016;70(3):271-7.

17. Abramowitz SA, McLean KE, McKune SL, Bardosh KL, Fallah M, Monger J, et al. Community-centered responses to Ebola in urban Liberia: the view from below. PLoS Negl Trop Dis. 2015;9(4):e0003706.

18. Levey EJ, Oppenheim CE, Lange BC, Plasky NS, Harris BL, Lekpeh GG, Kekulah I, Henderson DC, Borba CP. A qualitative analysis of factors impacting resilience among youth in post-conflict Liberia. Child Adolesc Psychiatry Ment Health. 2016;10:26. 
19. Levey EJ, Oppenheim CE, Lange BC, Plasky NS, Harris BL, Lekpeh GG, et al. A qualitative analysis of factors impacting resilience among youth in postconflict Liberia. Child Adolesc Psychiatry Ment Health. 2016;10:26.

20. Raguin G, French ESTHER network. The ESTHER hospital partnership initiative: a powerful levy for building capacities to combat the HIV pandemic in low-resource countries. Global Health. 2016;12:12.

21. Lubogo M, Donewell B, Godbless L, Shabani S, Maeda J, Temba H, Malibiche TC, Berhanu N. Ebola virus disease outbreak; the role of field epidemiology training programme in the fight against the epidemic, Liberia, 2014. Pan Afr Med J. 2015;22 Suppl 1:5.

22. Gebreyes WA, Dupouy-Camet J, Newport MJ, Oliveira CJ, Schlesinger LS, Saif YM, Kariuki S, Saif L, Saville W, Wittum T, Hoet A, Quessy S, Kazwala R, Tekola B, Shryock T, Bisesi M, Patchanee P, Boonmar S, King LJ. The global one health paradigm: challenges and opportunities for tackling infectious diseases at the human, animal, and environment interface in low-resource settings. PLoS Negl Trop Dis. 2014;8(11):e3257.

23. Ravi SJ1, Gauldin EM. Sociocultural Dimensions of the Ebola Virus Disease Outbreak in Liberia. Biosecur Bioterror. 2014 Oct 23. PMID:25341052

24. Moll R, Reece S, Cosford P, Kessel A. The Ebola epidemic and public health response. Br Med Bull. 2016;117(1):15-23.

25. Haverkort JJ, Minderhoud AL, Wind JD, Leenen LP, Hoepelman Al, Ellerbroek PM. Hospital preparations for viral hemorrhagic fever patients and experience gained from admission of an Ebola patient. Emerg Infect Dis. 2016;22(2):184-91.

26. Knipe DM, Whelan SP. Rethinking the response to emerging microbes: vaccines and therapeutics in the Ebola Era-a conference at Harvard medical school. J Virol. 2015;89(15):7446-8. doi:10.1128/JVI.01251-15.

27. Love CB, Arnesen SJ, Phillips SJ. Ebola outbreak response: the role of information resources and the national library of medicine. Disaster Med Public Health Prep. 2014;17:1-4.

28. Nabyonga-Orem J, Gebrikidane M, Mwisongo A. Assessing policy dialogues and the role of context: Liberian case study before and during the Ebola outbreak. BMC Health Serv Res. 2016;16 Suppl 4:219.

29. Smith MJ, Silva DS. Ethics for pandemics beyond influenza: Ebola, drugresistant tuberculosis, and anticipating future ethical challenges in pandemic preparedness and response. Monash Bioeth Rev. 2015;33(2-3): $130-47$

30. Hadi TA, Fleshler K. Integrating social media monitoring into public health emergency response operations. Disaster Med Public Health Prep. 2016;27:1-6.

31. Mwesiga A. Reporting epidemics: newspapers, information dissemination and the story of Ebola in the Ugandan district of Luweero. Pan Afr Med J. 2011;9:43.

32. Hewlett BS, Epelboin A, Hewlett BL, Formenty P. Medical anthropology and Ebola in Congo: cultural models and humanistic care. Bull Soc Pathol Exot. 2005;98(3):230-6.

33. Formenty $P$, Epelboin A, Allarangar $Y$, Libama F, Boumandouki $P$, Koné $L$, Molamou A, Gami N, Mombouli JV, Martinez MG, Ngampo S. Training the trainers seminar and analysis of the Ebola virus hemorrhagic fever outbreaks in central Africa from 2001 to 2004. (Brazzaville, Républic of Congo, April 68, 2004]. Bull Soc Pathol Exot. 2005;98(3):244-54.

34. Yakubu A, Folayan MO, Sani-Gwarzo N, Nguku P, Peterson K, Brown B. The Ebola outbreak in Western Africa: ethical obligations for care. J Med Ethics. 2014. doi:10.1136/medethics-2014-102434.

35. Leroy EM, Labouba I, Maganga GD, Berthet N. Ebola in West Africa: The outbreak able to change many things. Clin Microbiol Infect. 2014. doi:10.1111/1469-0691.12781.

36. Ameme DK, Nyarko KM, Afari EA, Antara S, Sackey SO, Wurapa F. Training Ghanaian frontline healthcare workers in public health surveillance and disease outbreak investigation and response. Pan Afr Med J. 2016;25 Suppl 1:2.

37. van Ree JW. Changing world, changing doctors, changing education!. Sante Publique. 2003 Apr;15 Spec No:151-5.

38. Tambo E. Non-conventional humanitarian interventions on Ebola outbreak crisis in West Africa: health, ethics and legal implications. Infect Dis Poverty. 2014:3:42.

39. Petinaux $B$, Ferguson $B$, Walker $M$, Lee $Y$ J, Little G, Parenti $D$, Simon G. $A$ proposed emergency management program for acute care facilities in response to a highly virulent infectious disease. J Emerg Manag. 2016;14(1):17-29.

\section{Submit your next manuscript to BioMed Central and we will help you at every step:}

- We accept pre-submission inquiries

- Our selector tool helps you to find the most relevant journal

- We provide round the clock customer support

- Convenient online submission

- Thorough peer review

- Inclusion in PubMed and all major indexing services

- Maximum visibility for your research

Submit your manuscript at www.biomedcentral.com/submit
Biomed Central 